\title{
PENGARUH UKURAN PERUSAHAAN, STRUKTUR ASET, PERTUMBUHAN PENJUALAN, PROFITABILITAS DAN CURRENT RATIO TERHADAP STRUKTUR MODAL PADA PERUSAHAAN MANUFAKTUR YANG TERDAFTAR DI BURSA EFEK INDONESIA
}

\author{
THE EFFECT OF COMPANY SIZE, ASSET STRUCTURE, SALES GROWTH, \\ PROFITABILITY AND CURRENT RATIO ON CAPITAL STRUCTURE IN THE \\ LISTED MANUFACTURING COMPANIES IN INDONESIA STOCK EXCHANGE
}

\author{
Veronika Marsaulina Lumbantoruan ${ }^{1}$, Bayu Wulandari², Jelita Wanna Naibaho ${ }^{3}$, \\ Winna Regina ${ }^{4}$, R. Chairuddin Zufriansyah ${ }^{5}$, Frengki Okto ${ }^{6}$ \\ Universitas Prima Indonesia ${ }^{1,2,3,4,5,6}$ \\ marsaulina.veronika@yahoo.co.id ${ }^{1}$
}

\begin{abstract}
The amount of assets owned by the company is the value of the size of the company. This study aims to test whether company size, asset structure, sales growth, profitability and current ratio have an influence on the capital structure of manufacturing companies listed on the Indonesia Stock Exchange (BEI). This type of research is quantitative descriptive, using 144 manufacturing companies listed on the IDX. This study uses a sampling method, namely purposive sampling and has obtained as many as 216 samples. This study uses data in the form of annual financial reports from each sample company published on the website www.idx.co.id. The variables related to this study are company size, asset structure, profitability, sales growth, and current ratio. The research method used is descriptive method and multiple linear regression analysis method. The results showed that Company Size, Asset Structure, Profitability and Current Ratio had no significant effect on capital structure. Meanwhile, sales growth has a significant effect on the capital structure. Simultaneously, Company Size, Asset Structure, Profitability, Sales Growth and Current Ratio together have a significant and significant effect on the company's capital structure as measured by the capital structure listed on the IDX.
\end{abstract}

Keywords: Company Size, Asset Structure, Sales Growth, Profitability, Current Ratio, and Capital Structure.

\begin{abstract}
ABSTRAK
Besarnya asset yang dimiliki perusahaan merupakan nilai dari ukuran perusahaan. Penelitian ini bertujuan untuk menguji apakah ukuran perusahaan, struktur aset, pertumbuhan penjualan, profitabilitas dan current ratio mempunyai pengaruh terhadap struktur modal pada perusahaan manufaktur yang terdaftar di Bursa Efek Indonesia (BEI). Jenis penelitian yang digunakan yaitu deskriptif kuantitatif, memakai 144 Perusahaan manufaktur yang terdaftar BEI. Penelitian ini menggunakan metode pengambilan sampel yaitu purposive sampling dan telah diperoleh sebanyak 216 sampel. Penelitian ini menggunakan data berupa laporan keuangan tahunan dari setiap perusahaan sampel yang dipublikasikan melalui situs www.idx.co.id. Adapun variable yang berkaitan dengan penelitian ini adalah ukuran perusahaan, struktur asset, profitabilitas, pertumbuhan penjualan, dan current ratio. Metode penelitian yang dipakai
\end{abstract}


ialah metode deskriptif dan metode analisis regresi linear berganda. Hasil penelitian menunjukkan bahwa Ukuran Perusahaan, Struktur Aset, Profitabilitas dan Current Ratio tidak berpengaruh nyata terhadap struktur modal. Sedangkan, Pertumbuhan penjualan berpengaruh nyata terhadap struktur modal. Secara simultan, Ukuran Perusahaan, Struktur Aset, Profitabilitas, Pertumbuhan Penjualan dan Current Ratio bersama-sama berpengaruh dan signifikan terhadap Stuktur Modal perusahaan diukur dari struktur modal yang terdaftar di BEI.

Kata Kunci: Ukuran Perusahaan, Struktur Aset, Pertumbuhan Penjualan, Profitabilitas, Current Ratio dan Struktur Modal.

\section{PENDAHULUAN}

Pada dunia persaingan bisnis dalam perkembangan era globalisasi khususnya dalam bidang perekonomian setiap perusahaan tentu saja akan mengembangkan produk atau melakukan perluasan usaha untuk meningkatkan penjualan atau laba perusahaan semaksimal mungkin, dalam melakukan hal ini diperlukan sumber pendanaan atau modal yang cukup agar dapat bertahan dalam persaingan dunia bisnis yang semakin berkembang dari tahun ke tahun.

Besarnya asset yang dimiliki perusahaan merupakan nilai dari ukuran perusahaan tersebut. Pertumbuhan asset sangat diharapkan bagi perkembangan perusahaan baik secara internal maupun eksternal. Pertumbuhan asset yang tinggi memberikan nilai bagi pertumbuhan perusahaan, semakin besar ukuran perusahaan akan memudahkan perusahaan dalam mendapatkan modal atau pendanaan. Karena bagi investor, pertumbuhan perusahaan yang baik berbanding lurus atas perkembangan dari tingkat pengembalian investasi yang diberikan.

Asset tetap yang dimiliki perusahaan juga menjadi fakor yang mempengaruhi struktur modal, karena asset tetap adalah asset yang dapat dipakai sebagai jaminan untuk memperoleh persetujuan pemberian pinjaman utang yang dapat dijadikan

sebagai tambahan modal bagi perusahaan.

Perusahaan yang mempunyai profitabilitas tinggi terhadap laba, maka laba ditahan akan lebih meningkat sehingga perusahaan cenderung akan lebih memilih memakai laba ditahan sebelum memakai hutang sebagai pendanaan investasi. Penjualan sangat penting bagi perusahaan agar barang atau jasa yang dihasilkan dapat memberikan keuntungan atau penghasilan bagi perusahaan maupun investor. Pertumbuhan penjualan yang tinggi menunjukkan bahwa perusahaan tersebut berkembang, dalam hal ini modal yang cukup sangat diperlukan dalam melakukan proses produksi. Apabila penjualan setiap tahun atau setiap bulan meningkat atau stabil maka perusahaan akan memperoleh tambahan modal lebih dari pinjaman.

Current Ratio
kesanggupan perusahaan $\begin{array}{r}\text { adalah } \\ \text { dalam }\end{array}$
membayar kewajiban jangka pendek.
Perusahaan yang memiliki likuiditas
yang besar biasanya tidak memakai
pembiayaan dari hutang karena pada
perusahaan yang memiliki tingkat
likuiditas yang besar biasanya memiliki
dana internal yang cukup.
Perusahaan dalam bidang
manufaktur merupakan perusahaan yang
mengolah bahan mentah menjadi barang
jadi atau barang stengah jadi. Perusahaan
manufaktur merupakan salah satu
perusahaan penopang perekonomian


yang memberikan kontribusi yang baik bagi perekonomian Indonesia dimana ekonomi kita tumbuh di angka 5,07\% pada tahun 2017 menjadi $5,17 \%$ di tahun 2018. Industri manufaktur juga memegang peran penting dalam perdagangan internasional mengingat hasil output yang dihasilkan cukup baik sehingga dapat bersaing dalam perdagangan internasional. Berdasarkan laporan Nikkei, Indeks Manajer Pembelian (Purchasing Managers Index / PMI) Perusahaan manufaktur bulan januari 2019 berada di level 49,1 menjadi 50,1 di bulan februari 2019, level diatas 50 menunjukan sector manufaktur tengah ekspansif. Dengan semakin meningkatnya tingkat persaingan, perusahaan manufaktur juga dituntut untuk mengeluarkan output yang bagus agar dapat bersaing dengan perusahaan lain dan mendapatkan laba semaksimal mungkin.

Berdasarkan uraian di atas, dapat kita ketahui agar dapat bersaing dengan perusahaan yang lain pada era ini perusahaan harus memiliki modal yang cukup agar dapat mengeluarkan produk yang bagus dan yang sesuai dengan kebutuhan masyarakat, dengan tercapainya perencanaan yang telah dilaksanakan maka dapat mensejahterahkan perusahaan maupun investor. Hal ini yang menyebabkan penulis menjadikan alasan mengambil sampel dari perusahaan manufaktur.

Table fenomena berikut ini menunjukkan Total Aset, Aset Tetap, Laba setelah Pajak, Penjualan, Aktiva lancar dan Total Hutang dari beberapa Perusahaan Manufaktur yang terdaftar di Bursa Efek Indonesia 2016-2018.

Tabel 1. Total Aset, Aset Tetap, Penjualan, Laba setelah Pajak, Aktiva Lancar, dan Total Hutang pada Perusahaan Manufaktur yang terdaftar di Bursa Efek Indonesia (BEI)

\begin{tabular}{|c|c|c|c|c|c|c|c|}
\hline $\begin{array}{c}\text { Kode } \\
\text { Emiten }\end{array}$ & Tahun & $\begin{array}{c}\text { Total } \\
\text { Aset }(\mathbf{R p})\end{array}$ & $\begin{array}{c}\text { Aset } \\
\text { Tetap (Rp) }\end{array}$ & $\begin{array}{l}\text { Penjualan } \\
\quad \text { (Rp) }\end{array}$ & $\begin{array}{c}\text { Laba setelah } \\
\text { pajak } \\
\text { (Rp) }\end{array}$ & $\begin{array}{c}\text { Aktiva } \\
\text { Lancar (Rp) }\end{array}$ & $\begin{array}{c}\text { Total Hutang } \\
\text { (Rp) }\end{array}$ \\
\hline \multirow[t]{6}{*}{ SIDO } & \multirow[t]{2}{*}{2016} & 2.987 .614 .00 & 1.051 .227 .000 & 2.561 .806 .00 & 480.525 .000 & 1.794 .125 .00 & 229.729 .000 .0 \\
\hline & & 0.000 & 000 & 0.000 & 000 & 0.000 & 00 \\
\hline & \multirow[t]{2}{*}{2017} & 3.158 .198 .00 & 1.215 .176 .000 & 2.573 .840 .00 & 533.799 .000 & 1.628 .901 .00 & 262.333 .000 .0 \\
\hline & & 0.000 & 000 & 0.000 & 000 & 0.000 & 00 \\
\hline & \multirow[t]{2}{*}{2018} & 3.337 .628 .00 & 1.553 .362 .000 & 2.763 .292 .00 & 663.849 .000$. & \multirow{2}{*}{$\begin{array}{l}1.547 .666 .00 \\
0.000\end{array}$} & 435.014 .000 .0 \\
\hline & & 0.000 & 000 & 0.000 & 000 & & 00 \\
\hline \multirow[t]{6}{*}{ JPFA } & \multirow[t]{2}{*}{2016} & 19.251 .026 .0 & 7.512.091.000. & 27.063 .310 .0 & 2.171 .608 .00 & \multirow{2}{*}{$\begin{array}{l}10.755 .503 .0 \\
00.000\end{array}$} & 9.878 .062 .000 \\
\hline & & 00.000 & 000 & 00.000 & 0.000 & & .000 \\
\hline & \multirow[t]{2}{*}{2017} & 21.088 .870 .0 & 8.346 .028 .000 & 29.602 .688 .0 & 1.107 .810 .00 & \multirow{2}{*}{$\begin{array}{l}11.189 .325 .0 \\
00.000\end{array}$} & 11.293 .242 .00 \\
\hline & & 00.000 & 000 & 00.000 & 0.000 & & 0.000 \\
\hline & \multirow[t]{2}{*}{2018} & 23.038 .028 .0 & 7.935.353.000. & 34.012 .965 .0 & 2.253 .201 .00 & \multirow{2}{*}{$\begin{array}{l}12.415 .809 .0 \\
00.000\end{array}$} & 12.823 .219 .00 \\
\hline & & 00.000 & 000 & 00.000 & 0.000 & & 0.000 \\
\hline \multirow{6}{*}{ ARNA } & \multirow[t]{2}{*}{2016} & 1.543 .216 .29 & 858.698 .468 .3 & 1.511 .978 .36 & 91.375 .910 .9 & \multirow{3}{*}{$\begin{array}{l}642.892 .045 . \\
913 \\
740.190 .524\end{array}$} & 595.128 .097 .8 \\
\hline & & 9.146 & 13 & 7.218 & 75 & & 87 \\
\hline & \multirow[t]{2}{*}{2017} & 1.601 .346 .56 & 833.704 .877 .0 & 1.732 .985 .36 & 122.183 .909$. & & 571.946 .769 .0 \\
\hline & & 1.573 & 50 & 1.870 & 643 & $\begin{array}{l}740.190 .524 . \\
246\end{array}$ & 34 \\
\hline & \multirow[t]{2}{*}{2018} & 1.652 .905 .98 & 795.547 .807 .9 & 1.971 .478 .07 & 158.207 .798 & \multirow{2}{*}{$\begin{array}{l}827.587 .984 . \\
112\end{array}$} & 556.309 .556 .6 \\
\hline & & 5.730 & 11 & 0.171 & 602 & & 26 \\
\hline
\end{tabular}

Sumber: $w w w . i d x . c o . i d$ 
Berdasarkan uraian yang telah disajikan, maka peneliti tertarik untuk melakukan penelitian dengan judul : "Pengaruh Ukuran Perusahaan, Struktur Aset, Pertumbuhan Penjualan, Profitabilitas dan Current Ratio terhadap Struktur Modal pada Perusahaan Manufaktur yang Terdaftar di Bursa Efek Indonesia.”

Ukuran perusahaan menggambarkan besar kecilnya suatu perusahaan, dimana perusahaan besar biasanya mempunyai reputasi cukup baik di mata masyarakat yang akan memudahkan perusahaan dalam memperoleh pinjaman dalam bentuk hutang ataupun modal saham dari pihak luar (Sartono, 2012).

Ukuran Perusahaan ialah hubungan fleksibilitas dan kesanggupan untuk memperoleh dana dan juga laba dengan memperhatikan pertumbuhan penjualannya (Haruman, 2018).

Menurut Mulyawan

ukuran perusahaan mengisyaratkan bahwa semakin besar suatu perusahaan, semakin besar pula tingkat hutangnya. Perusahaan yang lebih besar yang mana sahamnya tersebar sangat luas akan lebih berani mencabut saham baru dalam mencukupi kebutuhannya untuk membiayai pertumbuhan penjualannya dari pada perusahaan yang skala kecil. Sehingga semakin tinggi ukuran perusahaan, kecenderungan perusahaan untuk menggunakan dana eksternal juga semakin tinggi.

Wild \& Subramanyam (2010) mengatakan bahwa aktiva sebagai aset, aset ialah sumber daya yang dimiliki suatu perusahaan dengan tujuan menghasilkan laba. Semakin besar jumlah asset tetap yang dimiliki perusahaan maka perusahaan juga dapat menggunakan hutang dengan jumlah yang besar karena ukuran perusahaan besar biasanya lebih mudah mendapatkan akses ke sumber dana dibandingkan perusahaan kecil.

Besarnya aset tetap dapat sebagai jaminan dari hutang perusahaan (Sartono, 2012).

Menurut Rudianto (2012), aktiva ialah sumber daya yang dimiliki perusahaan. Aktiva ialah kumpulan dari seluruh kekayaan yang dimiliki perusahaan dan dipakai untuk mendapatkan pendapatan selama tahun berjalan maupun tahun-tahun berikutnya. Pertumbuhan asset berbanding terbalik dengan struktur modal. Perusahaan dengan pertumbuhan asset tinggi biasanya akan memakai dana internal karena perusahaan dianggap mampu membiayai kegiatan operasional dengan memakai asset yang dimiliki. Apabila pertumbuhan asset tinggi maka struktur modal akan mengalami penurunan.

Pertumbuhan penjualan ialah selisih antara jumlah penjualan tahun ini dengan tahun sebelumnya dibandingkan dengan penjualan tahun sebelumnya. Untuk perusahaan yang memiliki tingkat pertumbuhan tinggi biasanya akan menggunakan hutang lebih tinggi dibandingkan perusahaan yang tingkat pertumbuhan penjualannya kecil. Perusahaan yang penjua-lannya relatif stabil cenderung aman memperoleh lebih banyak pinjaman dan menanggung beban tetap yang lebih besar daripada perusahaan dengan penjualan tidak stabil (WIjaya et al., 2014)

Perusahaan akan memakai utang yang relatif lebih rendah apabila perusahaan mempunyai tingkat pengembalian atas investasi yang tinggi sehingga memungkinkan perusahaan membiayai sebagian besar kebutuhan pendanaannya dengan dana internal perusahaan (Wijaya et al., 2014). Pengembalian atas investasi modal ialah indikator penting dalam mengukur kekuatan perusahaan untuk jangka panjang dan dapat dipakai untuk 
menganalisis likuiditas jangka pendek (Wild \& Subramanyam, 2010).

Profitabilitas dapat mempengaruhi struktur modal perusahaan, dimana perusahaan yang menghasilkan laba lebih tinggi biasanya memiliki laba ditahan lebih tinggi sehingga untuk melakukan ekspansi perusahaan dapat penuhi dananya yang bersumber dari dana internal perusahaan (Wijaya et al., 2014).

Masalah likuiditas berhubungan dengan kesanggupan suatu perusahaan untuk memenuhi kewajiban jangka pendeknya. Pecking order theory mengatakan perusahaan cenderung memilih memakai pendanaan dari internal perusahaan. Perusahaan yang cenderung memiliki likuiditas yang besar akan mengurangi pendanaaan melalui utang. Salah satu rasio likuiditas (liquidity ratio) yang paling umum dipakai adalah current ratio (Primantara \& Dewi, 2016)

Likuiditas (CR) berfungsi untuk mengetahui kemampuan perusahaan dalam memenuhi dan membiayai hutang atau kewajiban pada saat ditagih atau pada saat jatuh tempo (Kasmir, 2012).

Eviani (2016) dalam teori pecking order mengatakan perusahaan akan lebih memilih membiayai perusahaan dengan dana internal, sehingga teori ini memprediksi adanya hubungan yang negatif antara likuiditas dan struktur modal.

Ambarwati (2010) mengatakan struktur modal merupakan perimbangan atau kombinasi antara hutang dan modal sendiri (saham preferen dan saham biasa) yang dipakai perusahaan untuk memprediksi dalam memperoleh modal. Faktor yang mempengaruhi struktur modal ialah stabilitas penjualan, struktur aktiva, leverage operasi, risiko bisnis, tingkat pertumbuhan, profitabilitas, pajak, pengendalian, sikap manajemen, ukuran perusahaan dan fleksibilitas keuangan.

\section{METODE PENELITIAN Tempat dan Waktu Penelitian}

Lokasi penelitian dilaksanakan di Bursa Efek Indonesia (BEI) melalui website www.idx.co.id dan beberapa dari situs website perusahaan masingmasing pada perusahaan manufaktur dengan pengambilan data laporan keuangan tahunan dari tahun 2016 sampai tahun 2018. Waktu penelitian dilaksanakan bulan januari 2018 sampai dengan april 2018.

\section{Jenis Penelitian}

Jenis penelitian ini ialah jenis penelitian deskriptif kuantitatif. Rumusan masalah deskriptif ialah suatu rumusan masalah yang berkenaan dengan pertanyaan terhadap keberadaan variabel mandiri, baik hanya pada satu variabel atau lebih (variabel yang berdiri sendiri).

\section{Populasi dan Sample}

Populasi ialah wilayah generalisasi yang terdiri atas objek/subjek yang memiliki kualitas dan karakteristik tertentu yang telah ditentukan oleh peneliti untuk dipelajari dan kemudian ditarik kesimpulannya. Metode penentuan sampel yang dipakai ialah purpossive sampling ialah teknik penentuan sampel dengan pertimbangan tertentu (Sugiono, 2009).

Kriteria-kriteria pengambilan sampel dalam purposive sampling adalah :

1. Perusahaan manufaktur yang terdaftar di Bursa Efek Indonesia dari tahun 2016-2018.

2. Perusahaan manufaktur yang mempublikasikan secara berturutturut laporan keuangan dari tahun 2016-2018.

3. Perusahaan manufaktur yang 
memdapat laba secara berturut-turut dari tahun 2016-2018.

Tabel 2. Sampel Penelitian

\begin{tabular}{clc}
\hline No. & \multicolumn{1}{c}{ Keterangan } & Jumlah \\
\hline 1 & $\begin{array}{l}\text { Perusahaan manufaktur } \\
\text { yang terdaftar di BEI }\end{array}$ & 144 \\
\hline 2 & $\begin{array}{l}\text { Perusahaan manufaktur } \\
\text { yang }\end{array}$ & $\begin{array}{r}\text { tidak } \\
\text { mempublikasikan } \\
\text { keuangannya } \\
\text { laporan } \\
\text { berturut-turut } \\
\text { periode 2016-2018. }\end{array}$ \\
& $\begin{array}{r}\text { secara } \\
\text { selama }\end{array}$ \\
\hline 3 & $\begin{array}{l}\text { Perusahaan manufaktur } \\
\text { yang mengalami kerugian }\end{array}$ & $(39)$ \\
pada periode 2016-2018. & \\
\hline Jumlah Penelitian & $\mathbf{8 5}$ \\
\hline Total Sampel ( 85 perusahaan x & $\mathbf{2 5 5}$ \\
3 tahun) &
\end{tabular}

\section{Teknik Pengumpulan Data}

Metode pengumpulan data dalam penelitian ini adalah dengan studi dokumentasi yang dimana teknik pengumpulan data dengan cara mencatat, mengumpulkan, dan mempelajari data- data perusahaan terkait masalah yang sedang diteliti mengenai ukuran perusahaan, struktur aset, profitabilitas, pertumbuhan penjualan dan current ratio setiap sampel dengan bersumber dari laporan keuangan perusahaan manufaktur yang dipublikasi di Bursa Efek Indonesia (BEI) sejak tahun 2016 sampai tahun 2018.

\section{Model Analisis Data Penelitian Model Penelitian}

Penelitian ini mengunakan metode regresi berganda merupakan teknik yang digunakan untuk menguji dan menganalisis, baik secara bersamaan ataupun parsial pengaruh beberapa variabel independen (X) terhadap satu variabel dependen (Y), yang dikerjakan dengan menggunakan program komputer SPSS (Statistical Package for Social Science).

Model analsisis data ini untuk mengetahui pengaruh variabel bebas (independen) dan variabel terikat (dependen) digunakan rumus analisis regresi linier berganda sebagai berikut:

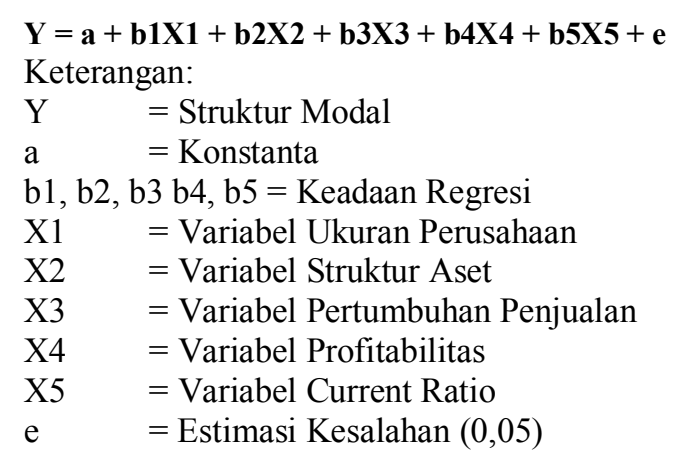

\section{Koefisien Determinasi (R2)}

Analisis determinasi dipakai untuk mengetahui presentase sumbangan pengaruh variabel independen (ukuran perusahaan, struktur aset, pertumbuhan penjualan, profitabilitas dan current ratio) secara serentak terhadap variabel dependen (struktur modal).

\section{Pengujian Hipotesis Secara Simultan (uji F)}

Uji-F digunakan untuk mengukur pengaruh variabel independen, secara bersama-sama atau simultan terhadap variabel dependen. Kriteria uji-F sebagai berikut:

a. Apabila F-hitung < F-tabel, maka Ho diterima.

b. Apabila F-hitung > F-tabel, maka Ho ditolak.

\section{Pengujian Hipotesis Secara Parsial} (uji t)

Uji-t digunakan untuk mengukur pengaruh variabel independen secara parsial terhadap variabel dependen. Kriterianya uji-t sebagai berikut.

a. Jika t-tabel $<$ t-hitung $<$ t-tabel, maka Ho diterima.

b. Jika t-hitung $>\mathrm{t}$-tabel atau t-hitung $<\mathrm{t}$-tabel, maka Ho ditolak. 


\section{HASIL DAN PEMBAHASAN Statistik Deskriptif Data}

Pada penelitian ini jumlah sampel dari laporan keuangan Perusahaan Manufaktur di Bursa Efek Indoensia dari tahun 2016 sampai 2018 adalah berjumlah 157 sampel. Statistik deskriptif ini memberikan gambaran nilai minimum, nilai maksimum, nilai rata - rata, dan standart deviasi.

Berikut hasil pengolaan data sampel dapat di lihat dari statistik deskriptif di bawah ini :

Tabel 3. Statistik Deskriptif Descriptive Statistics

\begin{tabular}{|c|c|c|c|c|}
\hline & $\mathrm{N}$ & $\begin{array}{l}\text { Mini } \\
\text { mum }\end{array}$ & $\begin{array}{l}\text { Maxi Mean } \\
\text { mum }\end{array}$ & $\begin{array}{c}\text { Std. } \\
\text { Deviatio } \\
\mathrm{n}\end{array}$ \\
\hline UP & 157 & 25.816 & $\begin{array}{r}32.20128 .892 \\
94 \\
\end{array}$ & $\begin{array}{r}1.43615 \\
6 \\
\end{array}$ \\
\hline SA & 157 & .009 & .752 .40812 & .164106 \\
\hline PP & 157 & -.148 & .532 .08408 & .106576 \\
\hline ROE & 157 & .001 & .300 .10039 & .070696 \\
\hline $\mathrm{CR}$ & 157 & .342 & $\begin{array}{r}5.2602 .2313 \\
6 \\
\end{array}$ & $\begin{array}{r}1.17317 \\
7 \\
\end{array}$ \\
\hline SM & 157 & .115 & 2.375 .77941 & .540061 \\
\hline $\begin{array}{l}\text { Valid N } \\
\text { (listwise } \\
\text { ) } \\
\end{array}$ & 157 & & & \\
\hline
\end{tabular}

Tabel 3 diatas menunjukkan nilai dengan rincian sebagai berikut :

1. Variabel ukuran perusahaan mempunyai jumlah sampel sebanyak 157, dengan nilai minimum 25,816 yaitu PT Lionmesh Prima Tbk di tahun 2016 dan nilai maksimum 32,201 yaitu PT Indofood Sukses Makmur Tbk di tahun 2018.

2. Variabel struktur aset mempunyai jumlah sampel sebanyak 157, dengan nilai minimum 0,009 yaitu PT Tempo Scan Pasifik Tbk di tahun 2016 dan nilai maksimum 0,752 yaitu PT Mulia Industrindo Tbk di tahun 2017.

3. Variabel pertumbuhan penjualan mempunyai jumlah sampel sebanyak
157, dengan nilai minimum $-0,148$ yaitu PT Wilmar Cahaya Indonesia Tbk di tahun 2018 dan nilai maksimum 0,532 yaitu PT Intan Wijaya International Tbk di tahun 2017.

4. Variabel profitabilitas mempunyai jumlah sampel sebanyak 157, dengan nilai minimum 0,001 yaitu PT Star Petrochem Tbk di tahun 2016 dan nilai maksimum 0,3 yaitu PT Selamat Sempurna Tbk di tahun 2016.

5. Variabel current ratio mempunyai jumlah sampel sebanyak 157, dengan nilai minimum 0,342 yaitu PT Sepatu Bata Tbk di tahun 2018 dan nilai maksimum 5,260 yaitu PT Mandom Indonesia Tbk di tahun 2016.

6. Variabel struktur modal mempunyai jumlah sampel sebanyak 157, dengan nilai minimum 0,115 yaitu PT Sri Rejeki Isman Tbk di tahun 2017 dan nilai maksimum 2,375 yaitu PT Jembo Cable Company Tbk di tahun 2016.

\section{Hasil Analisis Regresi Linear Berganda}

Analisis regresi linear berganda dipakai untuk mengetahui pengaruh Ukuran Perusahaan (UP), Struktur Aset (SA), Pertumbuhan Penjualan (PP), Profitabilitas (ROE), dan Current Ratio (CR) terhadap Struktur Modal (SM).

Tabel 4. Hasil Analisis Regresi Linear Berganda Coefficients ${ }^{a}$

\begin{tabular}{|c|c|c|c|c|c|}
\hline \multirow{3}{*}{ Model } & \multicolumn{3}{|c|}{$\begin{array}{l}\text { Unstandardize Standa } \\
\text { d Coefficients rdized }\end{array}$} & \multirow{3}{*}{$\mathrm{T}$} & \multirow{3}{*}{ Sig. } \\
\hline & & & $\begin{array}{l}\text { Coeffi } \\
\text { cients }\end{array}$ & & \\
\hline & B & $\begin{array}{c}\text { Std. } \\
\text { Error }\end{array}$ & $\overline{\text { Beta }}$ & & \\
\hline $\begin{array}{c}1 \text { (Constant } \\
\text { ) }\end{array}$ & 1.382 & .738 & & 1.872 & .063 \\
\hline UP & .004 & .026 & .010 & .145 & .885 \\
\hline SA & -.268 & .229 & -.081 & -1.170 & .244 \\
\hline $\mathrm{PP}$ & .809 & .341 & .160 & 2.374 & .019 \\
\hline ROE & -.543 & .576 & -.071 & -.943 & .347 \\
\hline
\end{tabular}


\begin{tabular}{llllll}
\hline CR & -.276 & .031 & -.600 & -8.920 & .000 \\
\hline
\end{tabular}

a. Dependent Variable: SM

Berdasarkan Tabel 4 diatas, diperoleh rumus regresi sebagai berikut: Struktur Modal $(\mathrm{SM})=1,382+0,004$ Ukuran Perusahaan - 0,268 Struktur Aset $+0,809$ Pertumbuhan Penjualan 0,543 Profitabilitas - 0,276 Current Ratio.

\section{Koefisien Determinasi Hipotesis}

Koefisien determinasi hipotesis dipakai untuk mengetahui seberapa besar pengaruh Ukuran Perusahaan (UP), Struktur Aset (SA), Pertumbuhan Penjualan (PP), Profitabilitas (ROE), dan Current Ratio (CR) terhadap Struktur Modal (SM).

Tabel 5. Koefisien Determinasi Model Summaryb

\begin{tabular}{rrrrr}
\hline Model & $\mathrm{R}$ & $\begin{array}{c}\mathrm{R} \\
\text { Square }\end{array}$ & $\begin{array}{c}\text { Adjusted R } \\
\text { Square }\end{array}$ & $\begin{array}{c}\text { Std. Error } \\
\text { of the } \\
\text { Estimate }\end{array}$ \\
\hline 1 & $612 \mathrm{a}$ & 374 & 354 & 434147
\end{tabular}

a. Predictors: (Constant), CR, UP, PP, SA, ROE

b. Dependent Variable: SM

Berdasarkan tabel 5 diatas, menunjukkan bahwa nilai Adjusted $R$ Square (R2) koefisien determinasi sebesar 0,354 yang berarti 35,4\%. Variabel independen berpengaruh pada struktur modal sebesar $35,4 \%$ sedangkan sisanya $64,6 \%$ dipengaruhi oleh variabel lainnya yang tidak teliti dalam penelitian ini.

\section{Pengujian Hipotesis Secara Simultan (Uji Statistik F)}

Uji $F$ dipakai untuk mengukur apakah Ukuran Perusahaan (UP), Struktur Aset (SA), Pertumbuhan Penjualan (PP), Profitabilitas (ROE), dan Current Ratio (CR) terhadap Struktur Modal (SM). Berdasarkan hasil pengolahan data dengan program SPSS, maka diperoleh hasil sebagai berikut:

Tabel 6. Hasil Uji Statistik F

\begin{tabular}{|c|c|c|c|c|c|c|}
\hline \multicolumn{7}{|c|}{ ANOVA $^{\text {b }}$} \\
\hline & \multirow[t]{2}{*}{ Model } & \multirow{2}{*}{$\begin{array}{l}\text { Sum of } \\
\text { Squares }\end{array}$} & & \multirow{2}{*}{$\begin{array}{l}\text { Mean } \\
\text { Square }\end{array}$} & \multirow[t]{2}{*}{$\bar{F}$} & \multirow[t]{2}{*}{ Sig. } \\
\hline & & & Df & & & \\
\hline \multirow[t]{3}{*}{$\overline{1}$} & Regression & 17.039 & 5 & 3.408 & 18.080 & $.000 \mathrm{a}$ \\
\hline & Residual & 28.461 & 151 & .188 & & \\
\hline & Total & 45.500 & 156 & & & \\
\hline
\end{tabular}

Berdasarkan Tabel 6 diatas, menunjukkan bahwa nilai Fhitung sebesar 18,080 dan nilai Ftabel dengan profitabilita 0,05 dan dilihat df1 dan df2 nya dengan rumus $\mathrm{df} 1=\mathrm{k}-1=(5+1)-1$ $=5$, df $2=\mathrm{n}-\mathrm{k}=157-6=151$ adalah sebesar 2,27 maka nilai Fhitung > Ftabel $(18,080>2,27)$ sehingga keputusannya adalah Ho ditolak dan $\mathrm{Ha}$ diterima, serta nilai signifikan lebih kecil dari 0,05 $(0,000<0,05)$. Dengan demikian dapat disim- pulkan bahwa variabel Ukuran Perusahaan (UP), Struktur Aset (SA), Pertumbuhan Penjualan (PP), Profitabilitas (ROE) dan Current Ratio (CR) bersama- sama berpengaruh secara signifikan terhadap variabel Struktur Modal (SM) pada perusahaan manufaktur yang terdaftar di BEI periode 2016-2018.

\section{Pengujian Hipotesis Secara Parsial (Uji Statistik t)}

Uji t dipakai untuk mengukur apakah variabel independen secara individual mempengaruhi variabel dependen. Berdasarkan hasil pengolahan data dengan program SPSS, maka diperoleh hasil uji $t$ sebagai berikut:

Tabel 7 Hasil Uji Statistik t

Coefficients

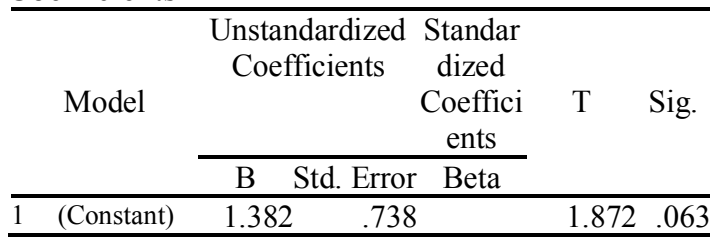




\begin{tabular}{lrrrrr}
\hline UP & .004 & .026 & .010 & .145 & .885 \\
\hline SA & -.268 & .229 & -.081 & -1.170 & .244 \\
\hline PP & .809 & .341 & .160 & 2.374 & .019 \\
\hline ROE & -.543 & .576 & -.071 & -.943 & .347 \\
\hline CR & -.276 & .031 & -.600 & -8.920 & .000 \\
\hline
\end{tabular}

Dependent Variable: SM

\section{Pengaruh Ukuran Perusahaan terhadap Struktur Modal}

Dari hasil pengujian secara parsial menyatakan bahwa Ukuran Perusahaan (UP) mempunyai nilai thitung adalah sebesar 0,145 , ttabel sebesar $\mathrm{t}$ df $=151$, diperoleh ttabel sebesar 1.975. Maka thitung $>$ ttabel $(0,145<1,975)$ dengan nilai signifikan $0,885>0,05$. Hal ini menunjukkan bahwa hasil hipotesis penelitian dimana ukuran perusahaan berpengaruh secara negatif dan tidak signifikan terhadap struktur modal perusahaan yang terdaftar di Bursa Efek Indoesia (BEI). Hasil penelitian bertolak belakang dengan pendapat Mulyawan (2015) dimana ukuran perusahaan mengisyaratkan bahwa semakin besar suatu perusahaan, semakin besar pula tingkat hutangnya.

\section{Pengaruh Struktur Aset terhadap Struktur Modal}

Dari hasil pengujian secara parsial menyatakan bahwa Struktur Aset (SA) mempunyai nilai thitung adalah sebesar $-1,170, t_{\text {tabel }}$ sebesar $\mathrm{t} d \mathrm{df}=151$, diperoleh $t_{\text {tabel }}$ sebesar -1,975. Maka $t_{\text {hitung }}>t_{\text {tabel }}(-0,1170>-1,975)$ dengan nilai signifikan $0,244>0,05$. Hal ini menunjukkan bahwa hasil hipotesis penelitian dimana struktur asset berpengaruh secara positif tetapi tidak signifikan terhadap struktur modal perusahaan yang terdaftar di Bursa Efek Indoesia (BEI). Hasil penelitian bertolak belakang dengan Primantara \& Dewi (2016) dimana Pertumbuhan asset berbanding terbalik dengan struktur modal. Perusahaan dengan pertumbuhan asset tinggi biasanya akan memakai dana internal karena perusahaan dianggap mampu membiayai kegiatan operasional dengan memakai asset yang dimiliki.

\section{Pengaruh Pertumbuhan Penjualan terhadap Struktur Modal}

Dari hasil pengujian secara parsial menyatakan bahwa Pertumbuhan Penjualan (PP) mempunyai nilai thitung adalah sebesar 2,374, tabel sebesar $t \mathrm{df}=$ 151, diperoleh $t_{\text {tabel }}$ sebesar 1,975. Maka $\mathrm{t}_{\text {hitung }}<\mathrm{t}_{\text {tabel }}(2,374>1,975)$ dengan nilai signifikan $0,019<0,05$. Hal ini menunjukkan bahwa hasil hipotesis penelitian dimana pertumbuhan penjualan berpengaruh secara positif dan signifikan terhadap struktur modal perusahaan yang terdaftar di Bursa Efek Indoesia (BEI). Perusahaan yang penjua-lannya relatif stabil cenderung aman memperoleh lebih banyak pinjaman dan menanggung beban tetap yang lebih besar daripada perusahaan dengan penjualan tidak stabil (Wijaya et al., 2014)

\section{Pengaruh Profitabilitas terhadap Struktur Modal}

Dari hasil pengujian secara parsial menyatakan bahwa Profitabilitas (ROE) mempunyai nilai $t_{\text {hitung }}$ adalah sebesar $-0,943$, tabel sebesar $\mathrm{t} d f=151$, diperoleh $t_{\text {tabel }}$ sebesar -1,975. Maka $t_{\text {hitung }}>t_{\text {tabel }}(-0,943>-1,975)$ dengan nilai signifikan $0,347>0,05$. Hal ini menunjukkan bahwa hasil hipotesis penelitian dimana profitabilitas berpengaruh secara positif tetapi tidak signifikan terhadap struktur modal perusahaan yang terdaftar di Bursa Efek Indoesia (BEI). Profitabilitas dapat mempengaruhi struktur modal perusahaan, dimana perusahaan yang menghasilkan laba lebih tinggi biasanya memiliki laba ditahan lebih tinggi sehingga untuk melakukan ekspansi perusahaan dapat penuhi dananya yang 
bersumber dari dana internal perusahaan (Wijaya et al., 2014)

\section{Pengaruh Current Ratio terhadap Struktur Modal}

Dari hasil pengujian secara parsial menyatakan bahwa Current Ratio (CR) memiliki nilai thitung adalah sebesar $-8,854, t_{\text {tabel }}$ sebesar $t \mathrm{df}$ $=151$, diperoleh $t_{\text {tabel }}$ sebesar $-1,975$. Maka $t_{\text {hitung }}<t_{\text {tabel }}(-8,920<-1,975)$ dengan nilai signifikan $0,000<0,05$. Hal ini menunjukkan bahwa hasil hipotesis penelitian dimana current ratio berpengaruh secara negatif dan signifikan terhadap struktur modal perusahaan yang terdaftar di Bursa Efek Indoesia (BEI). Likuiditas (CR) berfungsi untuk mengetahui kemampuan perusahaan dalam memenuhi dan membiayai hutang atau kewajiban pada saat ditagih atau pada saat jatuh tempo (Kasmir, 2012)

\section{PENUTUP}

\section{Kesimpulan}

Berdasarkan pada hasil penelitian yang diperoleh, maka dapat ditarik beberapa kesimpulan sebagai berikut :

1. Ukuran perusahaan secara parsial berpengaruh negatif dan tidak signifikan terhadap struktur modal (Studi Kasus pada Perusahaan Manufaktur yang terdaftar di Bursa Efek Indonesia Perode 2016 - 2018). Pada penelitian ini mengindikasikan bahwa kenaikan atau penurunan ukuran perusahaan tidak mempengaruhi struktur modal.

2. Struktur Aset secara parsial berpengaruh positif dan tidak signifikan terhadap struktur modal (Studi Kasus pada Perusahaan Manufaktur yang terdaftar di Bursa Efek Indonesia Perode 2016 - 2018) dan hal ini mengindikasikan bahwa kenaikan atau penurunan struktur aset dapat mempengaruhi struktur modal.

3. Pertumbuhan Penjualan secara parsial berpengaruh positif dan signifikan terhadap struktur modal (Studi Kasus pada Perusahaan Manufaktur yang terdaftar di Bursa Efek Indonesia Perode 2016 - 2018) dan hal ini mengindikasikan bahwa kenaikan atau penurunan pertumbuhan penjualan dapat mempengaruhi struktur modal.

4. Profitabilitas secara parsial berpengaruh positif dan tidak signifikan terhadap struktur modal (Studi Kasus pada Perusahaan Manufaktur yang terdaftar di Bursa Efek Indonesia Perode 2016 - 2018) dan hal ini mengindikasikan bahwa kenaikan atau penurunan profitabilitas dapat mempengaruhi struktur modal.

5. Current Ratio secara parsial berpengaruh negatif dan tidak signifikan terhadap struktur modal (Studi Kasus pada Perusahaan Manufaktur yang terdaftar di Bursa Efek Indonesia Perode 2016 - 2018) dan mengindikasikan bahwa kenaikan atau penurunan current ratio tidak mempengaruhi struktur modal.

6. Ukuran perusahaan, struktur asset, pertumbuhan penjualan, profitabilitas dan current ratio secara simultan berpengaruh signifikan terhadap struktur modal pada perusahaan manufaktur yang terdaftar di BEI periode 2016 - 2018 dengan koefisien determinasi $35,4 \%$.

\section{Saran}

Berdasarkan hasil penelitian dapat disarankan kepada perusahaan manufaktur yang terdaftar di Bursa Efek Indonesia agar lebih mengoptimalkan pendanaan atau struktur modalnya 
dengan kehatihatian dan memperhatikan tingkat resikonya, karena baik dan buruknya struktur modal akan mempengaruhi finansial perusahaan. Dengan optimalnya struktur modal maka akan dapat meningkatkan tingkat penjualan atau laba perusahaan.Bagi Peneliti selanjutnya untuk lebih lagi bekerja secara kelompok, memperluas bahasanya, menambah variabel independen dan juga lebih memperbanyak periode tahun pengamatan.

\section{DAFTAR PUSTAKA}

Ambarwati, S., D., A. (2010). Manajemen Keuangan Lanjut (Edisi 1). Graha Ilmu.Yogyakarta.

Eviani, A., D. (2016). Pengaruh struktur aktiva, pertumbuhan penjualan, dividend payout ratio, likuiditas dan profitabilitas terhadap struktur modal. Jurnal Akuntansi dan Sistem Teknologi Informasi, 11(2).

Haruman, T. (2018). Struktur Kepemilikan, Keputusan Keuangan dan Nilai Perusahaan. Finance and Banking Journal. Volume 10 (2):150- 165.

Kasmir. (2012). Analisis Laporan Keuangan. Cetakan keenam. PT Raja Grafindo Persada. Jakarta

Mulyawan, S. (2015). Manajemen Keuangan. Bandung. Pustaka Setia.

Primantara, A., N., A., D., Y., \& Dewi, M., R. (2016). Pengaruh likuiditas, profitabilitas, risiko bisnis, ukuran perusahaan, dan pajak terhadap struktur modal. E-Jurnal Manajemen Universitas Udayana, 5(5).

Rudianto. (2012). Pengantar Akuntansi Adaptasi IFRS. Jakarta. Erlangga.
Sartono, A. (2012). Manajemen Keuangan Teori dan Aplikasi. Edisi 4. BPFE. Yogyakarta.

Wijaya, I., P., A., S., Sucita, P., A., \& Utama, I., M., K. (2014). Pengaruh profitabilitas, struktur aset, dan pertumbuhan penjualan terhadap struktur modal serta harga saham. E-Jurnal Akuntansi Universitas Udayana, 6(3), 514-530.

Wild, John J. \& Subramanyam. (2010). Analisis Laporan Keuangan. Edisi 10. Jakarta. Salemba Empat. 